\title{
ANALYSIS OF IL-1Ra AND IL-4 GENE VNTRS POLYMORPHISMS AMONG DENTAL LABORATORY TECHNICIANS: A GENOTYPE-PHENOTYPE STUDY
}

\section{Diş Laboratuvarı Teknisyenlerinde $I L-1 R a$ ve $I L-4$ Geni VNTR Polimorfizmlerinin}

Analizi: Genotip-Fenotip Çalışması

\author{
Burcu YUKSEL ${ }^{1}$ (1) Serap ARSAL YILDIRIM² (1) \\ ${ }^{1,2}$ Kocaeli University, Vocational School of Kocaeli Health Services, Izmit
}

\begin{tabular}{ll}
\hline Gelis Tarihi / Received: 29.12.2020 & Kabul Tarihi / Accepted: 04.08 .2021 \\
\hline
\end{tabular}

\begin{abstract}
For people working in dental prosthesis laboratories (DPL), metal alloys and methylmethacrylate-based monomers and polymers used in the laboratory can pose occupational risks. These risks can cause occupational health problems and toxic effects on human health. This study purposes of researching the effects of occupational exposure because of dental prosthesis manufacturing operations on variable number tandem repeat (VNTR) polymorphisms in IL-1Ra and IL-4 genes. 29 DPL workers, the experimental group, were given a questionnaire, including the symptoms that might arise due to occupational exposure, and their responses were compared with 30 participants as a control group. Genotype distributions and allele frequencies for IL-1Ra intron 2 (rs2234663) and IL-4 intron 3 (rs79071878) VNTR polymorphisms were analyzed using the PCR technique. Both IL-1Ra intron 2 and IL-4 intron 3 polymorphisms identified from the experimental and control groups were not statistically significantly different $(p>.05)$. However, runny nose, burning throat, dyspnea and dryness and rash on the skin were significantly different when DPL workers were compared with the control group according to logistic regression analysis $(p<.05)$. No statistical difference was found in other phenotypic characters. However, due to the limited sample size, our results need to be confirmed in large-scale studies.
\end{abstract}

Keywords: Dental laboratory technicians, Interleukin-1 receptor antagonist, Interleukin-4, Occupational health and safety, Polymorphism.

\section{ÖZ}

Diş protez laboratuvarlarında (DPL) çalışan kişiler için laboratuvarda kullanılan metal alaşımları ve metilmetakrilat bazlı monomerler ve polimerler mesleki risk oluşturabilmektedir. Bu riskler mesleğe bağlı sağlık problemlerine ve insan sağlığında toksik etkilere sebep olabilir. Bu çalışmanın amacı dental protez üretim operasyonlarına bağlı mesleki maruziyetin IL-1Ra ve IL-4 genlerindeki değişken numaralı tandem tekrar (VNTR) polimorfizmleri üzerindeki etkilerini araştırmaktır. 29 DPL çalışanı deney grubu; 30 kontrol grubu ile karşılaştırılarak mesleki maruziyetlerine bağlı ortaya çıkacak semptomları da içine alan anket formları uygulanmıştır. IL-1Ra intron 2 (rs2234663) ve IL-4 intron 3 (rs79071878) VNTR polimorfizmleri için genotip dağılımları ve allel frekansları PCR tekniği kullanılarak analiz edilmiştir. Deney grubu ve kontrol grubundan belirlenen hem IL-1Ra intron 2 hem de IL-4 intron 3 polimorfizmleri istatistiksel olarak anlamlı bulunmamıştır ( $p$ >.05). Ancak DPL çalışanları lojistik regresyon analizine göre kontrol grubu ile karşılaştırıldığında burun akıntısı, boğaz yanması, nefes darlığı ve ciltte kuruluk ve kızarıklık gibi alanlarda anlamlı farklılıklar bulundu $(p<.05)$. Bununla birlikte, sınırlı örneklem büyüklüğü nedeniyle, sonuçlarımızın büyük ölçekli çalışmalarda doğrulanması gerekmektedir.

Anahtar kelimeler; Diş laboratuvarı teknisyenleri, İnterlökin-1 reseptör antagonisti, İnterlökin-4, İşs sağlığı ve güvenliği, Polimorfizm. 


\section{INTRODUCTION}

People working in dental prosthesis laboratories (DPL) are in constant interaction with restorative and auxiliary substances such as methyl methacrylate (MMA) based materials as monomers, polymers, and cement. These elements can cause side effects, including toxicity, allergic reactions and even carcinogenicity. Previous experimental and epidemiological research has shown the latent health risks of metal, acrylic and ceramic powder. (Choël, Grosgogeat, Bourgeois, \& Descotes, 1999; Hariyani, Berniyanti, \& Setyowati, 2015; Tadin et al., 2019). Besides, studies show that fine particle-sized dust ( $5 \mu \mathrm{m}$ and below) is spread into the working environment during the dental prosthesis production process (Arsal Y1ldirım \& Pekey, 2018; Hu et al., 2006). It is known that this particle size can reach the cells by passing through the dermal barrier and the circulatory system (Akkurt, 2014). Base metal alloys used in the dental prostheses are cobalt and zinc-containing chromium, nickel, molybdenum and small amounts of silica, beryllium, boron and carbon (Arsal Yıldırım, B. Pekey, \& H. Pekey, 2020; Sinitchi, 2017). While the contact of these metals with the skin during the manufacturing process triggers allergic reactions and systemic diseases in the skin, inhalation of the particulate matter can cause many respiratory system diseases, including pneumoconiosis and lung cancer (Abakay et al., 2013; Gupta, Rani, \& Garg, 2017; Hirano et al. 2018; Okamoto et al., 2017). Studies show that long-term treatment of chromium, nickel and cobalt metals has carcinogenic effects on humans (Arsal Y1ldırım et al., 2020; Sinitchi, 2017; Yuksel, 2021). Carcinogenic agents including asbestos, cadmium, carbon monoxide and carbon dioxide gases, volatile organic compounds, polycyclic aromatic hydrocarbons, elements (lead, nickel, etc.) and particulate matter are among the pollutants that put employee health at risk in the indoor air (Bernstein et al., 2008). Nickel, cobalt and molybdenum are utilized in combination with the alloys used in the manufacturation of dental prostheses (Hu et al., 2006; Kettelarij, Nilsson, Midander, Lidén, \& Julander, 2016). Chromium establishes 20-30\% of these cast alloys (Burgaz et al., 2002). Although chromium's most usual entry into the body is via the respiratory system, it can also penetrate via digestion and skin absorption, and its salts lead to harm in the cell by its strong oxidative effect (Arsal Y1ldırım \& Pekey, 2018). Exposure to nickel and cobalt may increase various lung cancer types (Burgaz et al., 2002). In vitro and in vivo research have indicated that chromium causes genetic mutations, makes single and double DNA strand breaks, causes various cellular damages, leads to DNA degradation, and causes DNA hyper conditioning (Fang et al., 2014; Rabbani-Chadegani, 2013). 
It is well known that some compounds, especially monomers such as acrylic acid, methacrylic acid and acrylamide, released from composite restorative materials used to form dental prostheses or in dental fillings may cause nonspecific inflammation reactions (Bakopoulou, Papadopoulos, \& Garefis, 2009; Durner, Wellner, Hickel, \& Reichl, 2012). Ansteinsson, Samuelsen, \& Dahl (2009) observed that silicate glasses without silanate, with an average size of $1 \mu \mathrm{m}$, which are frequently used in conventional hybrid composites, were marginally cytotoxic and induced interleukin-8 (IL-8) release.

The underlying factors that can lead to diseases are obvious. Many of the diseases are affected by exposure to metals in the workroom. If precautions are not taken, occupational exposure may harm human health, lead to disability or even the employee's death. Occupational diseases can be prevented by taking some simple precautions. This study aims to determine some symptoms caused by IL-1Ra (rs2234663), IL-4 (rs79071878) VNTR polymorphisms. The findings will raise awareness regarding the occupational risks of DPL employees encountered during dental prosthesis construction stages.

\section{MATERIAL AND METHOD}

\section{Study Group}

In this study, the participants' blood samples were collected to isolate DNA molecules and analyze IL-1Ra intron 2 (rs2234663) and IL-4 intron 3 (rs79071878) VNTR polymorphisms. The participants of this study were technicians working in DPLs $(n=29)$ in Kocaeli province (i.e., the experimental group) and 30 teachers and office workers (i.e., the control group). All participants completed a questionnaire form including some demographic information and 20 questions prepared by the researchers based on the Occupational and Environmental Diseases Assessment Form of the Turkish Thoracic Society (Akkurt, 2014). These questions focused on the symptoms of the employees about respiratory, skin, and eye diseases. The questionnaire aimed to identify the potential diseases that the technicians might be exposed to due to their working conditions. None of the members of the control group had a job or hobby related to metal alloys. They were also chosen from people who were not exposed to other chemicals. All participants were informed about the study techniques. Compliance with Ethical Standards, the Ethics Committee of Kocaeli University permitted the current research. Each blood sample was carried in EDTA tubes and transferred to the laboratory in ice packs in a container. 


\section{DNA extraction}

The blood samples taken from the participants were put into EDTA tubes and were taken to the laboratory facilities in ice batteries in a container $\left(4^{\circ} \mathrm{C}\right)$. Total DNA was isolated from blood according to the procedure specified by the manufacturer (the EURx GeneMATRIX Tissue \& Bacterial DNA Purification Kit). According to this procedure; The determined amount of blood was suspended in lysis buffer (a component of a DNA purification kit) and incubated with proteinase $\mathrm{K}$ for 10 minutes at $70^{\circ} \mathrm{C}$. Then, DNA was extracted by the manufacturer and using buffer solutions, which are the kit's components, in certain amounts. The extracted DNA was suspended in $100 \mu \mathrm{L}$ elution buffer. The quantity and purity of the isolated genomic DNA (gDNA) molecules were regulated using a Thermo Scientific NanoDrop TM 1000 Spectrophotometer, and the property was established by electrophoresis on $1 \%$ agarose gel. DNA extracts taken from blood samples were refrigerated at $-20^{\circ} \mathrm{C}$.

\section{Genotyping}

PCR amplification with specific primers (Table 1) was used to determine the genotyping of the genes (Mout, Willemze, \& Landegent, 1991; Settin, Zedan, Farag, El Regal, \& Osman, 2008). The PCR was used in a final reaction volume of $20 \mu \mathrm{L}$, including genomic DNA (10 ng), primers (10 pmol for each), and 5x FIREPol Master Mix (Solis BioDyne).

Table 1. Specific Primers Pairs for Amplification Of $I L-1 R a$ And $I L-4$ Gene Polymorphisms.

\begin{tabular}{lll}
\hline Gene & Primer & \\
\hline \multirow{2}{*}{$\boldsymbol{L}$-1 $\boldsymbol{R} \boldsymbol{a}$ VNTR $(\mathbf{r s 2 2 3 4 6 6 3 )}$} & F Primer & 5'-CTCAGCAACACTCCTAT-3'; \\
\hline $\boldsymbol{I L - 4}$ intron 3 VNTR & R Primer & 5'-TCCTGGTCTGCAGGTAA-3' \\
$(\mathbf{r s 7 9 0 7 1 8 7 8 )}$ & F Primer & 5'-AGGCTGAAAGGGGGAAAGC-3' \\
\hline
\end{tabular}

The PCR procedure for the IL-1Ra VNTR (rs2234663) included exposing samples to 4 min at $95^{\circ} \mathrm{C}$ for initial heat activation, 35 cycles of $30 \mathrm{~s}$ at $95^{\circ} \mathrm{C}$ for denaturing, $30 \mathrm{~s}$ at $58^{\circ} \mathrm{C}$ for annealing, $30 \mathrm{~s}$ at $72^{\circ} \mathrm{C}$ for elongation and $5 \mathrm{~min}$ at $72^{\circ} \mathrm{C}$ for a final extension. PCR products for IL-1Ra VNTR polymorphism were allele I (410 bp); allele II (240 bp); allele III (500 bp); allele IV (325 bp); allele V (595 bp). In the current study, alleles with three or more times, 86 bp repeats were labelled as (allele 1 , allele 2 and allele 3 ).

The PCR procedure for the IL-4 intron 3 VNTR (rs79071878) involved exposing samples to $4 \mathrm{~min}$ at $95^{\circ} \mathrm{C}$ for initial heat activation, 35 cycles of $30 \mathrm{~s}$ at $95^{\circ} \mathrm{C}$ for denaturing, $30 \mathrm{~s}$ at $55^{\circ} \mathrm{C}$ for annealing, $30 \mathrm{~s}$ at $72^{\circ} \mathrm{C}$ for elongation, and $5 \mathrm{~min}$ at $72^{\circ} \mathrm{C}$ for the final extension. PCR products for IL-4 3 VNTRs were allele R2 (253 bp); allele R1 (183 bp). 
DNA bands were detached by utilizing a $1.5 \%$ agarose gel $(100 \mathrm{~V}$ for $70 \mathrm{~V})$ and visualized with a UV transilluminator using Safe-T staining (ethidium bromide alternative).

\section{Statistical Analysis}

Statistical analysis for this study was carried out via SPSS 18. Chi-square analysis was used for the analysis of demographic characteristics (see Table 2 for details). Logistic regression analysis was used to compare the frequencies of phenotypic characteristics of DPL workers and the control group. The genotype distribution's variations within IL-1Ra intron 2 and IL-4 intron 3 polymorphisms from Hardy-Weinberg Equilibrium (HWE) test were determined using the chi-square test. All the studied samples met the HWE standards in both the DLP patients and individuals in the control group and were included in the current study. The p-value for significance was taken at the level of $p<.05$ for all statistical analyses.

\section{RESULTS}

According to the survey results, the personal data of 29 dental technicians and 30 control participants are shown in Table 2. It was seen that the mean age of DPL employees was quite similar to the control group. As shown in Table 2, the frequency of smoking and alcohol use is comparable between DPL technicians and control group participants $(p>.05)$.

Table 2. Demographic Information of the Participants.

\begin{tabular}{llll}
\hline Variable & $\begin{array}{l}\text { Experimental } \\
(\mathrm{n}=29)\end{array}$ & $\begin{array}{l}\text { Controls } \\
(\mathrm{n}=30)\end{array}$ & p value \\
\hline Age (years) & & & .089 \\
\hline $17-30$ & 5 & 6 & \\
\hline $31-40$ & 13 & 12 & .091 \\
\hline $41-56$ & 11 & $39.51 \pm 8.91$ & .074 \\
\hline Mean $( \pm$ S.D.) & $40.35 \pm 9.71$ & 21 & .103 \\
\hline Smoking & 19 & 9 & .135 \\
\hline Non-smoking & 10 & 13 & \\
\hline Alcohol consumers & 11 & 17 & \\
\hline Non-alcohol consumers & 18 & & \\
\hline Gender & & 11 & \\
\hline $\begin{array}{l}\text { Female } \\
\text { Male }\end{array}$ & 9 & 19 & \\
\hline Duration of exposure (years) Mean $( \pm$ & 20 & - & \\
$\quad$ S.D.) & $19.92 \pm 11.33$ & & \\
\hline
\end{tabular}

In Table 3, the frequencies of phenotypic characteristics of DPL workers and the control group were compared via logistic regression analysis. According to logistic regression analysis, results revealed a significant relationship between the runny nose, burning throat, dyspnea and dryness and rash on the skin and working in DPL $(p<.05)$. No statistical relationship was found 
in other phenotypic characters $(p>.05)$. Details of the logistic regression analysis are provided in Table 3.

Table 3 Analysis of Frequency Phenotypic Characteristics for DPL Workers and Control

\begin{tabular}{|c|c|c|c|c|c|}
\hline \multicolumn{6}{|c|}{ Frequency N(\%) } \\
\hline Parameters & & $\begin{array}{l}\text { DPL } \\
\text { Workers } \\
\mathrm{N}=29(\%)\end{array}$ & $\begin{array}{l}\text { Controls } \\
\mathrm{N}=30(\%)\end{array}$ & p-value & Logistic regression \\
\hline Presence of cancer & $\begin{array}{l}\text { None } \\
\text { Present }\end{array}$ & $\begin{array}{ll}21 & (72.4) \\
8 & (27.6) \\
\end{array}$ & $\begin{array}{l}26(86.7) \\
4(13.3) \\
\end{array}$ & .174 & 1.849 \\
\hline \multicolumn{6}{|l|}{ Eye } \\
\hline Rash & $\begin{array}{l}\text { None } \\
\text { Present } \\
\end{array}$ & $\begin{array}{l}23(79.3) \\
6(20.7) \\
\end{array}$ & $\begin{array}{l}14(46.7) \\
16(53.3) \\
\end{array}$ & .608 & .262 \\
\hline Itching & $\begin{array}{l}\text { None } \\
\text { Present }\end{array}$ & $\begin{array}{l}23(79.3) \\
6(20.7)\end{array}$ & $\begin{array}{l}25(83.3) \\
5(16.7)\end{array}$ & .108 & 2.590 \\
\hline Burning & $\begin{array}{l}\text { None } \\
\text { Present }\end{array}$ & $\begin{array}{l}23(79.3) \\
6(20.7)\end{array}$ & $\begin{array}{l}24(80) \\
6(20) \\
\end{array}$ & .254 & 1.303 \\
\hline Watery & $\begin{array}{l}\text { None } \\
\text { Present }\end{array}$ & $\begin{array}{l}23(79.3) \\
6(20.7) \\
\end{array}$ & $\begin{array}{l}21(70) \\
9(30)\end{array}$ & .503 & .449 \\
\hline \multicolumn{6}{|l|}{ Nose } \\
\hline Runny & $\begin{array}{l}\text { None } \\
\text { Present }\end{array}$ & $\begin{array}{l}22(75.9) \\
7(24.1)\end{array}$ & $\begin{array}{l}24(80) \\
6(20)\end{array}$ & $.019 *$ & 5.502 \\
\hline Itching & $\begin{array}{l}\text { None } \\
\text { Present }\end{array}$ & $\begin{array}{l}21(72.4) \\
8(27.6)\end{array}$ & $\begin{array}{l}23(76.7) \\
7 \quad(23.3)\end{array}$ & .118 & 2.448 \\
\hline Nasal Congestion & $\begin{array}{l}\text { None } \\
\text { Present }\end{array}$ & $\begin{array}{l}19(65.5) \\
10(34.5) \\
\end{array}$ & $\begin{array}{l}21(70) \\
9(30)\end{array}$ & .092 & 2.845 \\
\hline Sneeze & $\begin{array}{l}\text { None } \\
\text { Present }\end{array}$ & $\begin{array}{l}21(72.4) \\
8(27.6)\end{array}$ & $\begin{array}{l}24(80) \\
6(20)\end{array}$ & .058 & 3.601 \\
\hline \multicolumn{6}{|l|}{ Throat } \\
\hline Itching & $\begin{array}{l}\text { None } \\
\text { Present }\end{array}$ & $\begin{array}{l}27(93.1) \\
2(6.9)\end{array}$ & $\begin{array}{l}29(96.7) \\
1(3.33) \\
\end{array}$ & .311 & 1.026 \\
\hline Burning & $\begin{array}{l}\text { None } \\
\text { Present }\end{array}$ & $\begin{array}{l}28(96.6) \\
1(3.4)\end{array}$ & $\begin{array}{l}28(93.3) \\
2(1.7)\end{array}$ & $.019 *$ & 5.467 \\
\hline \multicolumn{6}{|l|}{ Respiratory } \\
\hline Wheezing & $\begin{array}{l}\text { None } \\
\text { Present }\end{array}$ & $\begin{array}{l}22(75.9) \\
7(24.1)\end{array}$ & $\begin{array}{l}26(86.7) \\
4(13.3)\end{array}$ & .069 & 3.306 \\
\hline Dyspnea & $\begin{array}{l}\text { None } \\
\text { Present }\end{array}$ & $\begin{array}{l}18(62.1) \\
11(37.9)\end{array}$ & $\begin{array}{l}19(63.3) \\
11(36.7)\end{array}$ & $.018 *$ & 5.617 \\
\hline Cough & $\begin{array}{l}\text { None } \\
\text { Present }\end{array}$ & $\begin{array}{l}19(65.5) \\
10(34.5)\end{array}$ & $\begin{array}{l}27(90) \\
3 \quad(10)\end{array}$ & .753 & .099 \\
\hline Sputum & $\begin{array}{l}\text { None } \\
\text { Present }\end{array}$ & $\begin{array}{l}21(72.4) \\
8(27.6)\end{array}$ & $\begin{array}{l}26(86.7) \\
4(13.3)\end{array}$ & .355 & .854 \\
\hline Skin & & & & & \\
\hline Rash & $\begin{array}{l}\text { None } \\
\text { Present }\end{array}$ & $\begin{array}{ll}20 & (69.0) \\
9 & (31.0) \\
\end{array}$ & $\begin{array}{l}20(66.7) \\
10(33.3) \\
\end{array}$ & $.003 *$ & 8.763 \\
\hline Itching & $\begin{array}{l}\text { None } \\
\text { Present }\end{array}$ & $\begin{array}{lc}20 & (69.0) \\
9 & (31.0)\end{array}$ & $\begin{array}{ll}26 & (86.7) \\
4 & (13.3)\end{array}$ & .234 & 1.417 \\
\hline Eruption & $\begin{array}{l}\text { None } \\
\text { Present }\end{array}$ & $\begin{array}{ll}25 & (86.2) \\
4 & (13.8)\end{array}$ & $\begin{array}{l}29(90) \\
1(10)\end{array}$ & .476 & .508 \\
\hline Dryness & $\begin{array}{l}\text { None } \\
\text { Present }\end{array}$ & $\begin{array}{l}15(51.7) \\
14(48.3)\end{array}$ & $\begin{array}{l}16(53.3) \\
14(46.7)\end{array}$ & $.002 *$ & 10.044 \\
\hline
\end{tabular}

${ }^{*} p<.05$ 
PCR products for IL-1Ra (rs2234663) PCR polymorphism: allele I (410 bp); allele II (240 bp); allele III (500 bp); allele IV (325 bp); allele V (595 bp) and IL-4 (rs79071878) gene polymorphisms; allele RP2 (253 bp); allele RP1 (183 bp) were separated by using a 1.5\% agarose gel (100 V for $70 \mathrm{~V})$ and visualized with a UV transilluminator using Safe-T staining (ethidium bromide alternative) (Figures 1 and 2).

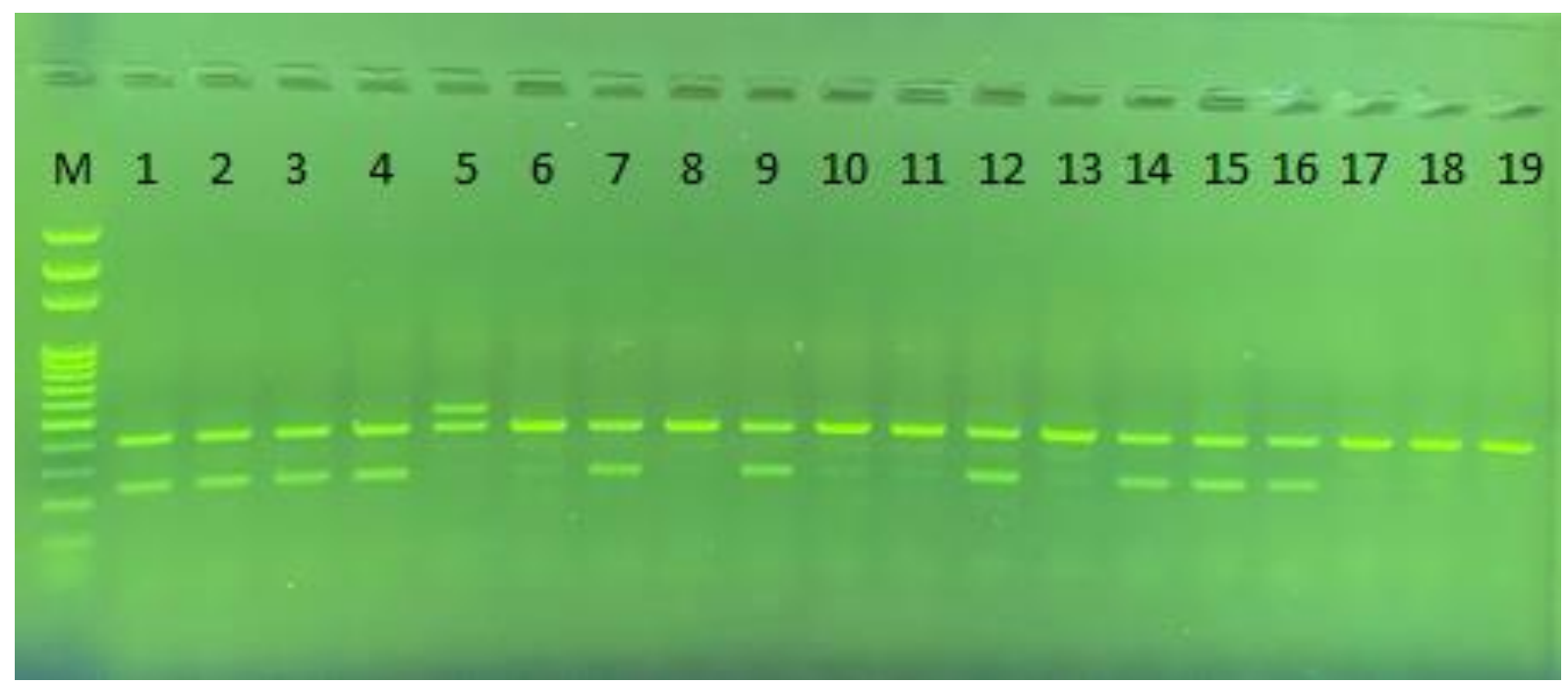

Figure 1. PCR Amplification for IL-1Ra (Rs2234663) Polymorphisms Show a Band Size of 410 Bp for 1 Allele, Band Size of 240 Bp for 2 Allele and a Band Size of 500 Bp for 3 Allele. Lane M Shows a DNA Size Marker (100 Bp). Lane 5 Shows the Only Band for the 1 and 3 Allele Giving Genotype 1/3 and 6,8,10,11,13,17,18,19 Shows for the 1 Allele 1/1 Giving Genotype. Lanes 1, 2,3, 4, 5,7,9,12,14,15,16 Show Only Band for The 1 and 2 Allele Giving The $1 / 2$ Genotype.

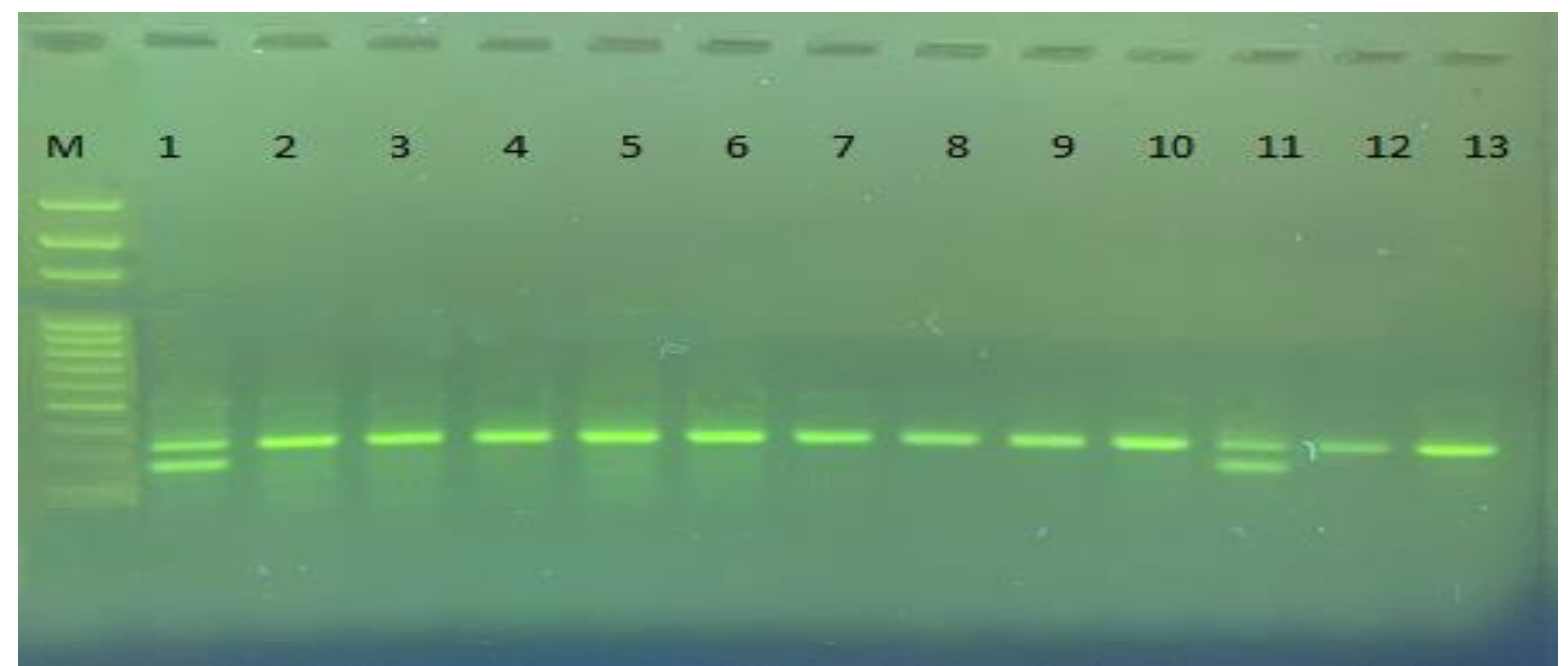

Figure 2. PCR Amplification for IL-4 (Rs79071878) Polymorphisms Show a Band Size of 253-Bp for the R2 Allele and a Band Size of 183-Bp for the R1 Allele. Lane M Shows a DNA Size Marker (100 Bp). Lane 1 Shows the Only Band for the R1 and R2 Allele Giving Genotype RP1/RP2 And 2,3,4,5,6,7,8,9,10,12 Shows for the R2 Allele RP2 Giving Genotype.

The Hardy - Weinberg Equilibrium test $(\mathrm{HWE})(\mathrm{p} 2+2 \mathrm{pq}+\mathrm{q} 2=1)$ was performed to examine the normal distribution of polymorphisms in IL-1Ra and IL-4 (intron 2 and intron 3) 
in both DPL workers and control groups. The differences between the expected, observed and calculated genotype frequencies between DPL workers and the control group were considered statistically significant $(p<.05)$.

The genotype distribution and allele frequencies of IL-1Ra intron 2 and IL-4 intron 3 VNTR polymorphisms in DPL workers and the control group are shown in Table 4. For the VNTR polymorphism of IL-1Ra intron 2 (rs2234663) in DPL workers; There is 1/1 genotype in $16(55.1 \%), 1 / 2$ genotype in $14(48.2 \%)$ and $1 / 3$ genotype in 1 person $(3.44 \%)$; In the control group, 13 subjects (43.3\%) have 1/1 genotype, 14 subjects (46.6\%) have $1 / 2$ genotype and 10 subjects (3\%) had 1/3 genotype. Genotype frequency of IL-1Ra rs2234663 polymorphism is not statistically significant in DPL workers and control group $(p=.444$, OR: $1.610,95 \% \mathrm{CI}=$ $0.691-3.753)$

Genotypes of the IL-4 intron 3 VNTR polymorphism (rs79071878) are shown as RP1 (183 PB), RP1 / RP2 (183 and 253 bp) and RP2 (253 bp). In DPL workers compared to the control group, the frequency of the R1 allele is $79.3 \%$ versus $73.3 \%$, and the frequency of the R2 allele is very close in both groups $(20.6 \%, 20.0 \%)$. When the frequency of RP1, RP1 / RP2 and RP2 genotypes were compared in the two groups, it was found $6.89 \%$ versus $23.3 \%, 17.2 \%$ versus $10.0 \%$ and $75.8 \%$ versus $70 \%$, respectively. Genotype frequency of IL-4 gene intron 3 VNTR polymorphism was not statistically significant in DPL workers and the control group ( $p$ $=.270$, OR: $1.272,95 \% \mathrm{CI}=0.687-2.357)$.

Table 4. The Genotypes and Allele Frequencies of Gene $I L-1 R a$ And $I L-4$ Genes In DPL Workers and Control Individuals

\begin{tabular}{|c|c|c|c|c|c|}
\hline Polymorphism & Alleles/Genotypes & $\begin{array}{c}\text { DPL } \\
\text { Workers } \\
\mathbf{N}=29(\%) \\
\end{array}$ & $\begin{array}{c}\text { Controls } \\
\mathrm{N}=30(\%)\end{array}$ & $\begin{array}{c}\text { p- } \\
\text { value }\end{array}$ & OR $(95 \%$ CI $)$ \\
\hline \multirow{5}{*}{$\begin{array}{l}\text { IL-4 Intron } 3 \\
\text { VNTR (70 bp) }\end{array}$} & R2 & $23(79.3)$ & $22(73.3)$ & & \\
\hline & $\mathrm{R} 1$ & $6(20.6)$ & $6(20.0)$ & & \\
\hline & RP2 & $22(75.8)$ & $21(70.0)$ & & \\
\hline & RP1/RP2 & $5(17.2)$ & $3(10.0)$ & .444 & $1.610(0.691-3.753)$ \\
\hline & RP1 & $2(6.89)$ & $7(23.3)$ & & \\
\hline \multirow{6}{*}{$\begin{array}{l}I L-1 R a \text { Intron } \\
2 \text { VNTR (86 } \\
\text { bp) }\end{array}$} & 1 & $29(100.0)$ & $29(96.6)$ & & \\
\hline & 2 & $13(44.8)$ & $6(20.0)$ & & \\
\hline & 3 & $1(3.44)$ & $3(10.0)$ & & \\
\hline & $1 / 1$ & $16(55.1)$ & $13(43.3)$ & & \\
\hline & $1 / 2$ & $14(48.2)$ & $14(46.6)$ & .270 & $1.272(0.687-2.357)$ \\
\hline & $1 / 3$ & $1(3.44)$ & $3(10.0)$ & & \\
\hline
\end{tabular}




\section{DISCUSSION}

DPL workers may contact many toxic substances, including hazardous metal and metal alloys (Arsal Y1ldırım et al., 2020; Hariyani et al., 2015; Kim et al., 2002; Yuksel, 2021). Previous research reports an increase in the complaints of the DPL technicians and the prevalence of pneumoconiosis (Arsal Y1ldirım \& Pekey, 2018; Hariyani et al., 2015; Hu et al., 2006; Kettelarij et al., 2016; Kim et al., 2002). This study investigated some symptoms and IL1Ra (rs2234663), IL-4 (rs79071878) VNTR polymorphisms during dental prosthesis construction stages caused by exposure to fine toxic particles. To our best knowledge, no previous study focused on IL-1Ra (rs2234663), IL-4 (rs79071878) VNTR among DPL technicians.

Genetic polymorphisms provided information about how individual differences contribute to certain diseases (Kuran, Aslan, Haytoğlu, Yüreğir, \& Bozdoğan, 2019). Some gene polymorphisms may increase the risk of a disease, or some polymorphic alleles may only show a disease risk under certain environmental conditions (Bingöl, Polat, \& Diler, 2020).

IL-1 receptor, connected to IL-1Ra is an antagonist anti-inflammatory cytokine in transmitting a biological signal (Zamani Badi, Nikzad, \& Karimian, 2018). IL-1 receptor antagonist gene polymorphism has been associated with a widespread species of diseases in the literature. Increased IL-1Ra plasma concentrations were found to correlate with disease severity in all asthmatic patients (Settin et al., 2008). Consistent with this, Joos et al. reported that the $\mathrm{R} 2$ allele has a protective effect on decreased lung function (Joos et al., 2001). It has been described that the IL-1Ra intron 2 VNTR polymorphism can alter IL-1Ra levels and affect the immune response (Kesarwani, Ahirwar, Mandhani, \& Mittal, 2008). Gene and haplotype profiles of patients with asthma and chronic obstructive airway disease (COPD) in this gene polymorphism have been mentioned in several studies (Dejan et al., 2009; Movahedi et al., 2008). In this study, we investigated the IL-1Ra (rs2234663) gene polymorphism of DPL technicians. There was no significant relationship between IL-1Ra intron 2 VNTR gene polymorphism in DPL workers and the control group. The mechanism of the relationship between the IL-1Ra intron 2 VNTR gene polymorphism and the toxic effect of occupational exposure is not clear. Contact dermatitis is common, especially in working areas where metal and chemical use is common, and the skin reactions of those working with IL-1Ra are parallel in studies (Jongh et al., 2006). Kezic, Visser, Verberk (2009) found a statistically significant difference in the IL-1 genes of workers exposed to low-level irritants and employees exposed 
to high-level irritants. One of the biggest limitations of our study is the number of

participants. Only a total of 29 DPL employees could be recruited for the study. We need to have more samples to have more accurate results. Larger sample sizes and functional studies are required to illuminate these findings further. Regression analyzes suggested that exposure status and personal habits had major effects on phenotypic parameters (runny nose, burning throat, dyspnea and dryness and rash on the skin) rather than genotypes $(p<.05)$.

Interleukin-4 is the main cytokine of $\mathrm{T}$ helper 2 lymphocytes, which has an antiinflammatory effect and has a key role in regulating humoral immune responses (Salimi, Mohammadoo-Khorasani, Yaghmaei, Mokhtari, \& Moossavi, 2014). IL-4 is one of the most studied cytokines in nasal polyposis, and increased IL-4 levels have been reported in several studies (Milonski et al., 2015; Zhang, Ni, Cai, Chen, \& Wang, 2012). IL-4 VNTR gene polymorphisms have also been associated with immune asthma in the current literature (Birbian, Singh, Jindal, \& Sobti, 2014). IL-4 can also be involved in cancer formation by inhibiting macrophage activity by cellular immunity. Some studies have shown that serum levels of these interleukins increase in cancer patients (Sosroseno, Herminajeng, \& Goeno, 1994; Tsai et al., 2005). VNTR polymorphism consisting of $70 \mathrm{bp}$ in the 3rd intron of the IL-4 gene affects the transcription activity through an enhancer or leads to cancer susceptibility through immunoglobulin E release (Yagi, Tanaka, Motomura, \& Kubo, 2007). According to our findings, a significant relationship was found between the polymorphism in the 3rd intron of the IL-4 gene and the effects associated with occupational conditions ( $p>.05)$. In addition, it is accepted that silica used in smoothing processes of metal prostheses in DPLs is also effective on the autoimmune system (Otsuki et al., 2007; Palabıyık, Girgin, Tutkun, Hiçyılmaz, \& Baydar, 2013). However, this argument is imprecise. Although these findings warrant further investigation through validation, these findings have existing evidence that the toxic effect of occupational exposure induces polymorphism in DPL workers (Chuang et al., 2004; Echeverria et al., 2006; Wan et al., 2006).

Büyüköztürk et al. (2015) found high levels of IL-4 due to exposure to high levels of Ni element in their study. In a study, Huang et al. (2015) found that Zinc oxide nanoparticles exposure could cause an increase in IL-4 in workers. Pukanha, Yimithrang, \& Kwanhian, (2020) concluded in their studies that Pb exposure might affect IL-4. Anlar et al. (2017) found an increase in IL-4 due to silica exposure in their studies on ceramic workers. In another study, the researchers found that nano-silica and quartz materials diminished the release of proinflammatory cytokines (IL-1 $\beta$ and TNF- $\alpha$ ) (Mathisen et al., 2015). Moreover, interleukin 
levels were found to be high in respiratory patients with chronic lung disease, particularly asthma (Tillie-Leblond et al., 1999). Other research revealed that exposure to composite dust did not change IL-1 levels but caused a decrease in IL-6 levels (Cokic et al., 2016). In another study conducted among dentists and dental technicians, researchers have examined the effect of mercury on the central nervous system and determined that mercury induces polymorphism against the CPOX4 gene in dentists. This can reveal how humans can be potentially influenced by the effect of $\mathrm{Hg}$ on central nervous system function, which might increase the vulnerability to $\mathrm{Hg}$-neurotoxicity (Echeverria et al., 2006).

Since DPL workers are simultaneously exposed to metal alloys, methyl methacrylatebased monomers or polymers, synergistic and antagonistic interactions may be between them (Garcia et al., 2002; Yuksel \& Arsal Yildirim 2021). Therefore, it is very unlikely to understand which compounds were in charge of the physical symptoms seen in the current study. The researchers also acknowledge that contact to metals in dental laboratories might be caused by exposure to the components of base metal alloys and the metals present in refractory materials and the abrasives utilized in the process of each casting plus denture finishing (Bernstein et al., 2008; Nayebzadeh \& Dufresne, 1999).

\section{CONCLUSION}

This study is the first study investigating the relationship between IL-1Ra (rs2234663), IL-4 (rs79071878) VNTR gene polymorphisms to the best of our knowledge DPL workers. As a result, both IL-1Ra intron 2 and IL-4 intron 3 polymorphisms determined from the experimental and control groups were not statistically significant. Further studies will help to understand the molecular mechanisms of the symptoms and polymorphisms that may occur due to occupational exposure and host interactions. It provides valuable information in identifying potentially degenerative diseases and in early pre-symptomatic diagnosis. However, our results are preliminary due to the limited sample size, and they require confirmation in further studies with larger samples.

\section{Acknowledgements}

Thanks to all lab technicians and controls who volunteered to participate. Also, thanks to Dr. Fikriye POLAT for her valuable contributions. 


\section{REFERENCES}

Abakay, A., Atilgan, S., Abakay, O., Atalay, Y., Guven, S., Yaman, F., Tanrikulu, A. C. (2013). Frequency of respiratory function disorders among dental laboratory technicians working under conditions of high dust concentration. Eur Rev Med Pharmacol Sci, 17(6), 809-814.

Akkurt, I. (2014). Occupational respiratory diseases. Ankara: Günes Medical Publisher (in Turkish).

Anlar, H.G., Bacanli, M., Iritaş, S., Bal, C., Kurt, T., Tutkun, E., ...Basaran, N. (2017) Effects of occupational silica exposure on oxidative stress and immune system parameters in ceramic workers in TURKEY. Journal of Toxicology and Environmental Health, Part A, 80, 13-15.

Ansteinsson, V. E., Samuelsen, J. T., Dahl, J. E. (2009). Filler particles used in dental biomaterials induce the production and release of inflammatory mediators in vitro. Journal of Biomedical Materials Research Part B: Applied Biomaterials: An Official Journal of The Society for Biomaterials, The Japanese Society for Biomaterials, and The Australian Society for Biomaterials and the Korean Society for Biomaterials, 89(1), 86-92.

Arsal Yıldirım S.,Pekey, B. (2018). Assessment of particulate matter-related pollution in the dental prosthesis laboratory air in terms of workers' health. Sakarya Üniversitesi Fen Bilimleri Enstitüsü Dergisi. 22(2), 838-852.

Arsal Yıldırım, S. A., Pekey, B., Pekey, H. (2020). Assessment of occupational exposure to fine particulate matter in dental prosthesis laboratories in Kocaeli, Turkey. Environmental monitoring and assessment, 192(10), $1-16$.

Bakopoulou, A., Papadopoulos, T., Garefis, P. (2009). Molecular toxicology of substances released from resinbased dental restorative materials. International journal of molecular sciences, 10(9), 3861-3899.

Bernstein, J. A., Alexis, N., Bacchus, H., Bernstein, I. L., Fritz, P., Horner, E., Reijula, K. (2008). The health effects of nonindustrial indoor air pollution. Journal of Allergy and Clinical Immunology, 121(3), 585-591.

Bingöl, G., Polat, F., Diler, S. B. (2020). Association of IL-1RA and IL-4 gene vntrs with susceptibility to prostate cancer in the Turkish population. Cytology and Genetics, 54(5), 487-492.

Birbian, N., Singh, J., Jindal, S. K., Sobti, R. C. (2014). High risk association of IL-4 VNTR polymorphism with asthma in a North Indian population. Cytokine, 66(1), 87-94.

Burgaz, S., Demircigil, G. Ç., Yllmazer, M., Ertaş, N., Kemaloğlu, Y., Burgaz, Y. (2002). Assessment of cytogenetic damage in lymphocytes and in exfoliated nasal cells of dental laboratory technicians exposed to chromium, cobalt, and nickel. Mutation Research/Genetic Toxicology and Environmental Mutagenesis, 521(1-2), 4756.

Büyüköztürk, S., Gelincik, A., Ünal, D., Demirtürk, M., Çelik, D.D., Erden, S., ...Erdem Kuruca, S.(2015). Oral nickel exposure may induce Type I hypersensitivity reaction in nickel-sensitized subjects. Int Immunopharmacol., 26(1), 92-96.

Choël, L., Grosgogeat, B., Bourgeois, D., Descotes, J. (1999). Occupational toxic risks in dental laboratory technicians. Journal of Environmental Medicine, 1(4), 307-314.

Chuang, H. Y., Yu, K. T., Ho, C. K., Wu, M. T., Lin, G. T., Wu, T. N. (2004). Investigations of vitamin D receptor polymorphism affecting workers' susceptibility to lead. Journal of occupational health, 46(4), 316-322.

Cokic, S. M., Hoet, P., Godderis, L., Wiemann, M., Asbach, C., Reichl, F. X., Van Landuyt, K. L. (2016). Cytotoxic effects of composite dust on human bronchial epithelial cells. Dental Materials, 32(12), 1482-1491. 
Dejan, T., Mirkovska, S. J., Aleksandar, P., Ana, S., Efinska, M. O., Emilija, S., Jean, G. (2009). Association of Cytokine Gene Polymorphisms with Chronic Obstructive. Iranian Journal of Allergy, Asthma and Immunology, 31-42.

Durner, J., Wellner, P., Hickel, R., Reichl, F. X. (2012). Synergistic interaction caused to human gingival fibroblasts from dental monomers. Dental Materials, 28(8), 818-823.

Echeverria, D., Woods, J. S., Heyer, N. J., Rohlman, D., Farin, F. M., Li, T., Garabedian, C. E. (2006). The association between a genetic polymorphism of coproporphyrinogen oxidase, dental mercury exposure and neurobehavioral response in humans. Neurotoxicology and teratology, 28(1), 39-48.

Fang, Z., Zhao, M., Zhen, H., Chen, L., Shi, P., Huang, Z. (2014). Genotoxicity of tri-and hexavalent chromium compounds in vivo and their modes of action on DNA damage in vitro. PloS one, 9(8), e103194

Garcia-Fernandez, A. J., Bayoumi, A. E., Perez-Pertejo, Y., Motas, M., Reguera, R. M., Ordonez, C., Ordonez, D. (2002). Alterations of the glutathione-redox balance induced by metals in CHO-K1 cells. Comparative Biochemistry and Physiology Part C: Toxicology \& Pharmacology, 132(3), 365-373

Gupta, S., Rani, S., Garg, S. (2017). Infection control knowledge and practice: A cross-sectional survey on dental laboratories in dental institutes of North India. The Journal of the Indian Prosthodontic Society, 17(4), 348 .

Hariyani, N., Berniyanti, T., Setyowati, D. (2015). Effects of occupational, environmental controls on the level of $\mathrm{Co}, \mathrm{Ni}$ and $\mathrm{Cr}$ among dental technicians. International Journal of Environmental Science and Development, 6(9), 643-647.

Hirano, T., Numakura, T., Moriyama, H., Saito, R., Shishikura, Y., Shiihara, J., Ichinose, M. (2018). The first case of multiple pulmonary granulomas with amyloid deposition in a dental technician; a rare manifestation as occupational lung disease. BMC pulmonary medicine, 18(1), 77.

Hu, S. W., Lin, Y. Y., Wu, T. C., Hong, C. C., Chan, C. C., Lung, S. C. C. (2006). Workplace air quality and lung function among dental laboratory technicians. American journal of industrial medicine, 49(2), 85-92.

Huang, K.L., Lee, Y.H., Chen, H.I., Liao, H.S., Chiang, B.L., Cheng, T.J. (2015). Zinc oxide nanoparticles induce eosinophilic airway inflammation in mice. J Hazard Mater., 297,304-12.

Jongh, C.M., Verberk, M.M., Withagen, C.E., Jacobs, J.J., Rustemeyer, T., Kezic, S (2006) Stratum corneum cytokines and skin irritation response to sodium lauryl sulfate. Contact Dermatitis 54, 325-33.

Joos, L., McIntyre, L., Ruan, J., Connett, J. E., Anthonisen, N. R., Weir, T. D., Sandford, A. J. (2001). Association of $I L-1 \beta$ and $I L-1$ receptor antagonist haplotypes with the rate of decline in lung function in smokers. Thorax, 56(11), 863-866.

Kesarwani, P., Ahirwar, D. K., Mandhani, A., Mittal, R. D. (2008). Association between- 174 G/C promoter polymorphism of the interleukin-6 gene and progression of prostate cancer in North Indian population. DNA and cell biology, 27(9), 505-510.

Kettelarij, J., Nilsson, S., Midander, K., Lidén, C., Julander, A. (2016). Snapshot of cobalt, chromium and nickel exposure in dental technicians. Contact Dermatitis, 75(6), 370-376.

Kezic, S., Visser, M.J., Verberk, M.M. (2009). Individual susceptibility to occupational contact dermatitis. Industrial Health, 47, 469-478.

Kim, T. S., Kim, H. A., Heo, Y., Park, Y., Park, C. Y., Roh, Y. M. (2002). Level of silica in the respirable dust inhaled by dental technicians with demonstration of respirable symptoms. Industrial Health, 40(3), 260265. 
Kuran, G., Aslan, H., Haytoğlu, S., Yüreğir, Ö. Ö., Bozdoğan, S. T. (2019). IL-IRN VNTR, IL-2 (-330), and IL-4 VNTR gene polymorphisms in patients with chronic rhinosinusitis with sinonasal polyposis. Turkish Journal of medical sciences, 49(5), 1411-1417.

Mathisen, G. H., Ansteinsson, V., Samuelsen, J. T., Becher, R., Dahl, J. E., Bølling, A. K. (2015). TEGDMA and filler particles from dental composites additively attenuate LPS-induced cytokine release from the macrophage cell line RAW 264.7. Clinical oral investigations, 19(1), 61-69.

Movahedi, M., Mahdaviani, S. A., Rezaei, N., Moradi, B., Dorkhosh, S., Amirzargar, A. A. (2008). IL-10, TGF- $\beta$, IL-2, IL-12, and IFN- $\gamma$ Cytokine Gene Polymorphisms in Asthma. Journal of Asthma, 45(9), 790-794.

Milonski, J., Zielinska-Blizniewska, H., Majsterek, I., Przybylowska-Sygut, K., Sitarek, P., Korzycka-Zaborowska, B., Olszewski, J. (2015). Expression of POSTN, IL-4, and IL-13 in chronic rhinosinusitis with nasal polyps. DNA and Cell Biology, 34(5), 342-349.

Mout, R., Willemze, R., Landegent, J. E. (1991). Repeat polymorphisms in the interleukin-4 gene (IL4). Nucleic Acids Research, 19(13), 3763 .

Nayebzadeh, A., Dufresne, A. (1999). Evaluation of exposure to methyl methacrylate among dental laboratory technicians. American Industrial Hygiene Association Journal, 60(5), 625-628.

Okamoto, M., Tominaga, M., Shimizu, S., Yano, C., Masuda, K., Nakamura, M., Kawayama, T. (2017). A Case of Dental Technicians' Pneumoconiosis. Internal Medicine, 8860-17.

Otsuki, T., Maeda, M., Murakami, S., Hayashi, H., Miura, Y., Kusaka, M., ...Nishimura, Y. (2007). Immunological effects of silica and asbestos. Cell Mol Immunol., (4)261-268.

Palabıylk, S.S.,Girgin, G.,Tutkun, E., Hiçyllmaz, O.H.,Baydar, T. (2013). Immunomodulation and oxidative stress in denim sandblasting workers: changes caused by silica exposure. Arh Hig Rada Toksikol., 64, 431-437.

Pukanha, K., Yimithrang, S., Kwanhian, W. (2020). The immunotoxicity of chronic exposure to high levels of lead: an ex vivo investigation. Toxics, 8, (56), 1-13.

Rabbani-Chadegani, A. (2013). Studies on the genotoxic effect of chromium oxide (Cr VI): Interaction with deoxyribonucleic acid in solution. Mutation Research/Genetic Toxicology and Environmental Mutagenesis, 750(1-2), 105-110.

Salimi, S., Mohammadoo-Khorasani, M., Yaghmaei, M., Mokhtari, M., Moossavi, M. (2014). Possible association of IL-4 VNTR polymorphism with susceptibility to preeclampsia. BioMed research international, 2014.

Settin, A., Zedan, M., Farag, M., El Regal, M. E., Osman, E. (2008). Gene polymorphisms of IL-6- 174 G/C and IL-1Ra VNTR in asthmatic children. The Indian Journal of Pediatrics, 75(10), 1019-1023.

Sinitchi, G. (2017). Zirconium allergies caused by oral dental materials. A general review. International Journal of Medical Dentistry, 21(2).

Sosroseno, W., Herminajeng, E., Goeno, S. (1994). The interleukin network in the immunopathogenesis of oral diseases. Asian Pacific Journal of allergy and immunology, 12(2), 161.

Tadin, A., Gavic, L., Jurkovic, I., Vidovic, N., Jerkovic, D., Zeljezic, D. (2019). Cytogenetic Biomonitoring of Dental Technicians: A Cross-Sectional Study. Journal of Prosthodontics, 28(2), 106-112.

Tillie-Leblond, I., Pugin, J., Marquette, C. H., Lamblin, C., Saulnier, F., Brichet, A., Gosset, P. (1999). Balance between pro-inflammatory cytokines and their inhibitors in bronchial lavage from patients with status asthmaticus. American journal of respiratory and critical care medicine, 159(2), 487-494. 
Tsai, F. J., Chang, C. H., Chen, C. C., Hsia, T. C., Chen, H. Y., Chen, W. C. (2005). Interleukin4 gene intron 3 polymorphism is associated with transitional cell carcinoma of the urinary bladder. BJU international, 95(3), 432-435.

Wan, J. X., Zhang, Z. B., Guan, J. R., Cao, D. Z., Ye, R., Jin, X. P., Xla, Z. L. (2006). Genetic Polymorphism of Toxicant Metabolizing Enzymes and Prognosis of Chinese Workers with Chronic Benzene Poisoning. Annals of the New York Academy of Sciences, 1076(1), 129-136.

Yagi, R., Tanaka, S., Motomura, Y., Kubo, M. (2007). Regulation of the Il4 gene is independently controlled by proximal and distal 3' enhancers in mast cells and basophils. Molecular and cellular biology, 27(23), 80878097.

Yuksel, B. (2021). Investigation of morphological abnormalities in red blood cells among dental laboratory technicians. Environmental Science and Pollution Research, 28(16), 20650-20658.

Yuksel, B., Arsal Yildirim, S. (2021). Determination of cytogenetic abnormalities in buccal mucosa of dental laboratory technicians. Archives of Environmental \& Occupational Health, 1-8.

Zamani Badi, T., Nikzad, H., Karimian, M. (2018). IL-1RA VNTR and IL-1 $\alpha$ 4845G> T polymorphisms and risk of idiopathic male infertility in Iranian men: A case-control study and an in silico analysis. Andrologia, 50(9), e13081.

Zhang, M. L., Ni, P. H., Cai, C. P., Chen, N. J., Wang, S. L. (2012). Association of susceptibility to chronic rhinosinusitis with genetic polymorphisms of IL-4 and IL-10. Zhonghua er bi yan hou tou jing wai ke za $z$ hi= Chinese journal of otorhinolaryngology head and neck surgery, 47(3), 212-217. 